\title{
THE ECONOMIC CRISIS AND IMMIGRATION: ROMANIAN CITIZENS IN THE CERAMIC TILE DISTRICT OF CASTELLÓ (SPAIN)
}

\author{
Joan Serafí BERNAT ${ }^{1)}$, Rafae/ VIRUELA ${ }^{2)}$ \\ 1) Jaume I University, Castelló, Spain, ${ }^{2)}$ University of Valencia, Spain
}

\begin{abstract}
Between 2001 and 2007 an exceptional number of immigrants arrived in the province of Castello (Spain), the majority of whom were from Romania, attracted by the plentiful employment prospects offered by a model of production based on the intensive labour requirements of the ceramic tile and construction industries. The effects of the international economic crisis have been particularly serious in the area of Castelló, where employment has fallen by $20 \%$ in just three years. Immigrations flows from Romania have fallen, while the number of those leaving has increased, and migration plans have been modified although the size of the immigrant stock has not fallen significantly due to continued family reunification. The differential between the Spanish and Romanian welfare states, the degree of adaptation in the host society and the strategies developed by the immigrant population explain why returning migrant numbers remain moderate and migratory circulation has increased.
\end{abstract}

Key Words: : Migration flows, economic crisis, Romanians, Castelló

\section{Introduction}

The province of Castelló (Spain) provides an excellent vantage point from which to study international economic migration patterns. During a period of substantial economic expansion, the region became a focal point for immigrants and has quickly attracted high numbers of new citizens. Studies have shown both neo-classical theories and the role of networks to be valid, particularly the network associated with the Adventist Church during the first stages of the migration process. In recent years, the serious downturn in the economic situation has led many migrant families to reassess their plans for the future, but difficulties in their country of origin, together with the speed and falling costs of today's communication and transport systems are generating new patterns of migration.

The aim of this paper is to evaluate recent changes among the Romanian population in the province of Castelló. The article begins with a summary of the changes in migration flows in Spain, followed by an explanation of the model of growth in the province. The characteristics of the resident Romanian population are then defined and the consequences of the crisis on the employment market, migration flows and stock are analysed. The paper concludes with an attempt to surmise the strategies Castello's Romanian community has adopted in response to the recession.

\section{The general and local context}

Over the last five hundred years Spain has been a major provider of migrant labour. The discovery and colonisation of the American continent mobilised some half a million Spaniards during the modern period (Martínez Shaw 1994). The period of highest migration coincided with 
the wave of large European migrations at the end of the nineteenth and beginning of the twentieth centuries, when the term 'mass migration' was coined (Sánchez Albornoz 1988), in which around four million Spaniards emigrated according to César Yáñez (1994), or slightly fewer according to Consuelo Naranjo (1992) and Blanca Sánchez Alonso (1995). At the same time, migration to Algeria and Morocco also began (Vilar 2004), and Europe was the third destination for Spanish migrants. The wake of the Spanish civil war (1936-39) scattered Spanish exiles across the globe. However, the period of most intense migration occurred during the 1960s and 1970s (García Fernández 1965 and Garmendia 1981), until it was curtailed by the 1973 energy crisis. In the following year the migration balance between Spain and Europe was reversed, and 1974 marked the beginning of a period of high returns. Between 1974 and 1980 around 400,000 migrants came back to Spain, while outward migration rapidly dwindled (Carreras and Tafunell 2005, I, 141).

In 2001 Spain's migration flows were equally balanced. The number of foreign residents registered in Spain in the census of 1 May 2001 was 1,572,000, while Spaniards living abroad at the same time amounted to approximately 1,431,000, of whom some 735,000 were resident in the Americas and 640,000 in Europe. However, a dramatic change has occurred in the last decade: Spain has shifted from being a supplier to a receiver of migrants. For several years, the number of arrivals has reflected Spain's global position as the second preference for those migrating abroad. The number of immigrants has increased exponentially and Spain is now the European Union country with the second highest number of foreign residents. On 1 January 2010, 5.7 million foreigners were resident in Spain, representing 12.2\% of the country's total population. What is specific to the situation in Spain, however, is the rapid pace with which these events have taken place, since in less than one decade Spain has achieved what has taken over forty years in other countries. Arrivals of immigrants en masse began in 2001 and continued through to 2008 . A second basic feature of this migration pattern is that is clearly economic migration, since $76 \%$ of the new citizens come from countries with a significantly lower per capita income than that of Spain.

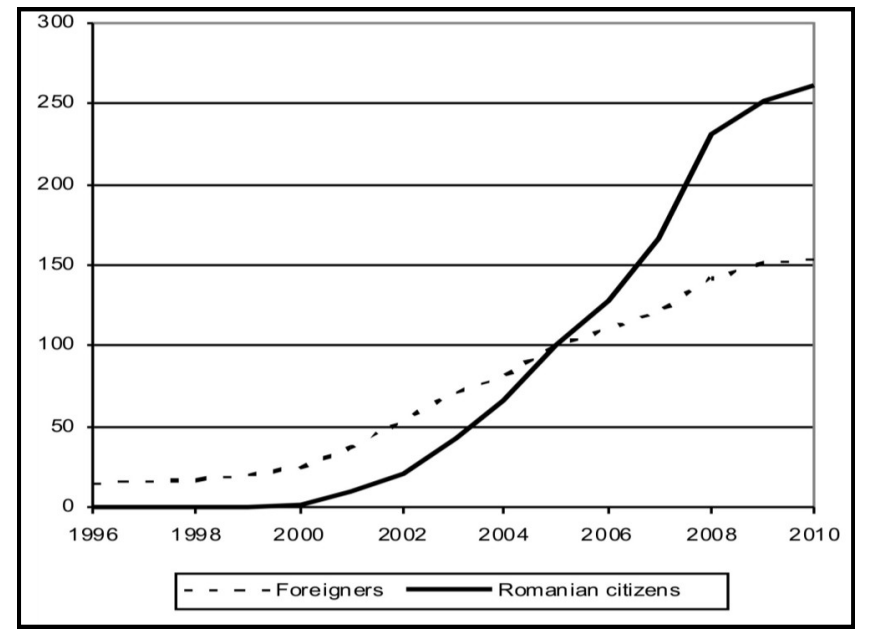

Fig. 1 - Stock of foreigners and Romanian citizens in Spain, 1996-2010. Base 100 in 2005. Source: INE (Spanish National Statistics Office), Padrón de Habitantes. 1996-2009. 
One of the most spectacular immigration streams is that of the Romanian population; not only was it the fastest growing (the trend did not begin until 2001), but it is also the nationality with the largest number of residents $(829,715$ on 1 January 2010$)$, the highest number of workers with a job contract and the most widespread nationality across the whole of Spain (Fig. 1). By 1 January 2008, the Romanian community was the largest immigrant group in Spain, and although migration flows have fallen since then, on 1 January 2010 it was still the largest foreign community, accounting for $14.5 \%$ of all foreigners.

The factors that have attracted millions of migrants to Spain, as noted by other authors (Aja, Arango and Oliver 2009; Cachon 2009; Pajares 2009; Reher and Requena 2009, among others), include the country's strong economic growth between 1998 and 2007, the large demand for labour in a range of sectors, the extensive hidden economy, the rapidly ageing Spanish population, the incorporation of women into the workforce and generous immigration policies that contrast with the restrictive measures adopted by traditional destination countries.

In the specific case of the Romanian community, additional factors are also significant: the particular circumstances of economic poverty in Romania during its transition to the market economy (Viruela 2004; Gimeno-Bernat 2006); the rapid cementing of migration chains and network links among families and neighbours from the same areas of Romania and through religious organisations (Domingo and Viruela 2001; Sandu 2007); the good professional reputation enjoyed by Eastern Europeans in the host community, where their training, level of education, etc., are appreciated (loé 2004; Pla 2008); and cultural affinity through a shared romance language. In addition to the above, ease of movement within the Schengen area was an important factor, first through visa exemption (1 January 2002) and then with the Romania's entry into the European Union (1 January 2007) and finally, Spanish migration policy, which encouraged the arrival of Eastern Europeans while at the same time restricting entry to other groups.

We now analyse the model of economic growth in the province of Castello. The province covers an area of $6,632 \mathrm{~km}^{2}$, and is located in the east of the Iberian peninsula, and in the north of the Valencian autonomous region. In the last twenty-five years it has been one of the most dynamic provinces in Spain, as evidenced by its vigorous macroeconomic indicators (investment, employment, exportation, etc.). As well as traditional commercial agriculture, the 1960s and 1970s witnessed the consolidation of a powerful industrialisation process, highly specialised in ceramic tile manufacture (Gimeno 1999). This sector expanded greatly until the start of the present century, and when growth levelled off, a hitherto unforeseen boom turned the residential construction industry into the driving force of the province's economy. These circumstances enabled the phase of expansion, initiated in 1993, to continue until the real estate bubble burst in September 2007. Throughout this period Castello's gross domestic product, in per capita terms, was significantly higher than that of both the Valencian autonomous region and of Spain as a whole, an even more significant achievement given the province's high demographic dynamism.

The ceramic tile cluster includes 25 municipalities and covers an area of $1,234 \mathrm{~km}^{2}$ in the centre and south of the province of Castello (Fig. 2). It is one of the best examples of industrial specialisation and geographical concentration, on a par with the Italian region of EmiliaRomagna with which it competes fiercely for the international market. As well as its long tradition and ready supply of raw material, the industry developed as a result of increased demand. The sector benefited from a huge stimulus in the mid-twentieth century based on the construction of tourist homes and apartments. It successfully weathered the crisis of the 1970s through heavy re-investment and the ensuing introduction of new technologies. The demand 
for raw materials, chemicals and machinery spawned the concentration of auxiliary industries in the same district. As Marshall (1891) and Becattini (1987) note, it is a mature industrial district, consolidated by a network of institutions and entities such as business and professional associations, and both public and private technological, research and training centres (Salom and Albertos 2006).
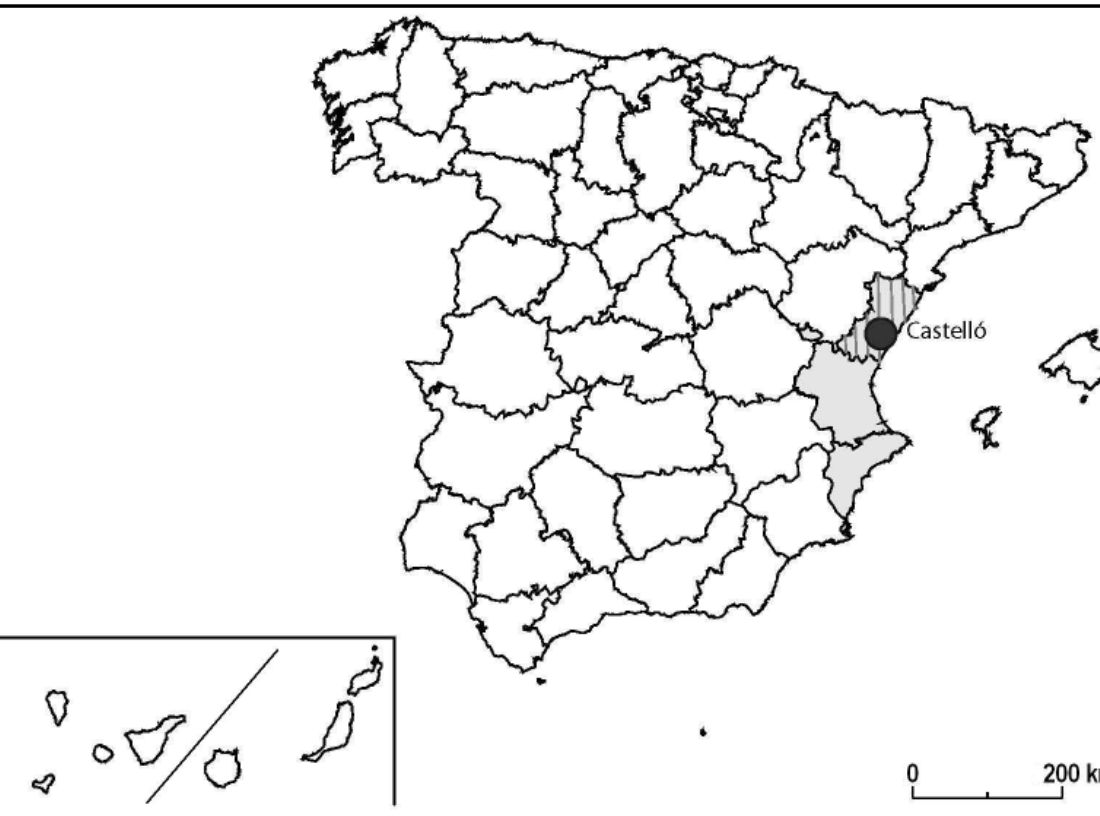

$\Delta$
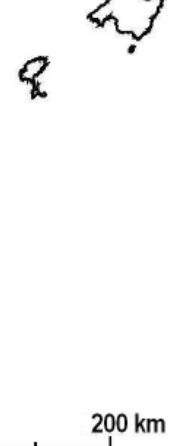

Valencian Region (NUT 2)

Castelló Province (NUT 3)

Fig. 2 - Location of the Valencian region, the province of Castelló and the ceramic tile cluster

The golden decade of the ceramic tile industry spanned from 1993 to 2002 . Production doubled to over 650 million square metres in the last year, $94 \%$ of the total Spanish output. The sector provided jobs for 35,000 workers directly - and possibly as many indirectly - the equivalent of roughly a third of the province's workforce. Sales reached 3,500 million euros, half of which were generated in foreign markets. According to the Active Population Survey (EPA) for the first quarter of 2003, Castelló ranked fourth out of the fifty Spanish provinces in terms of active industrial population. While percentages for agriculture and construction did not vary significantly from national averages, a large deficit was reported in the service sectors, which in $47^{\text {th }}$ position was ten points below the total for the whole country.

This area is one of the privileged regions in the Spanish and European Mediterranean Arc. It 
has financial and human capital and good transport infrastructure: major roads built to accommodate large volumes of traffic, railways, port facilities both in the capital, Castelló, and 60 kilometres south in Valencia, which handles most goods for export and is one of the busiest and most competitive ports in the Mediterranean. Ceramic tiles are one of the most important products exported from there: 2.4 million tons in 2009, which according to the Valencia Port Authority statistics department represents $10 \%$ of total volume handled by the port. However, the cluster has certain structural weaknesses (Fuertes et al. 2005) and because it relies heavily on exports and economic cycles, it is vulnerable, particularly in times of crisis such as the present moment.

The ceramic tile industry experienced setbacks at the beginning of 2003 that marked a turning point in previous trends. In the ensuing years lower demand prevented complete recovery, which weakened business confidence and slowed down investment. The international crisis hit the sector hard and in 2009 production had practically dropped by half. A significant proportion of the profits made during the boom decade were diverted to other sectors, including construction, which appeared to be the most profitable and expanded at an extraordinary pace. From just over 10,000 dwellings approved annually in the province by the College of Architects for the years 1999 to 2001, the number rose to 23,700 in 2006 (Fig. 3).

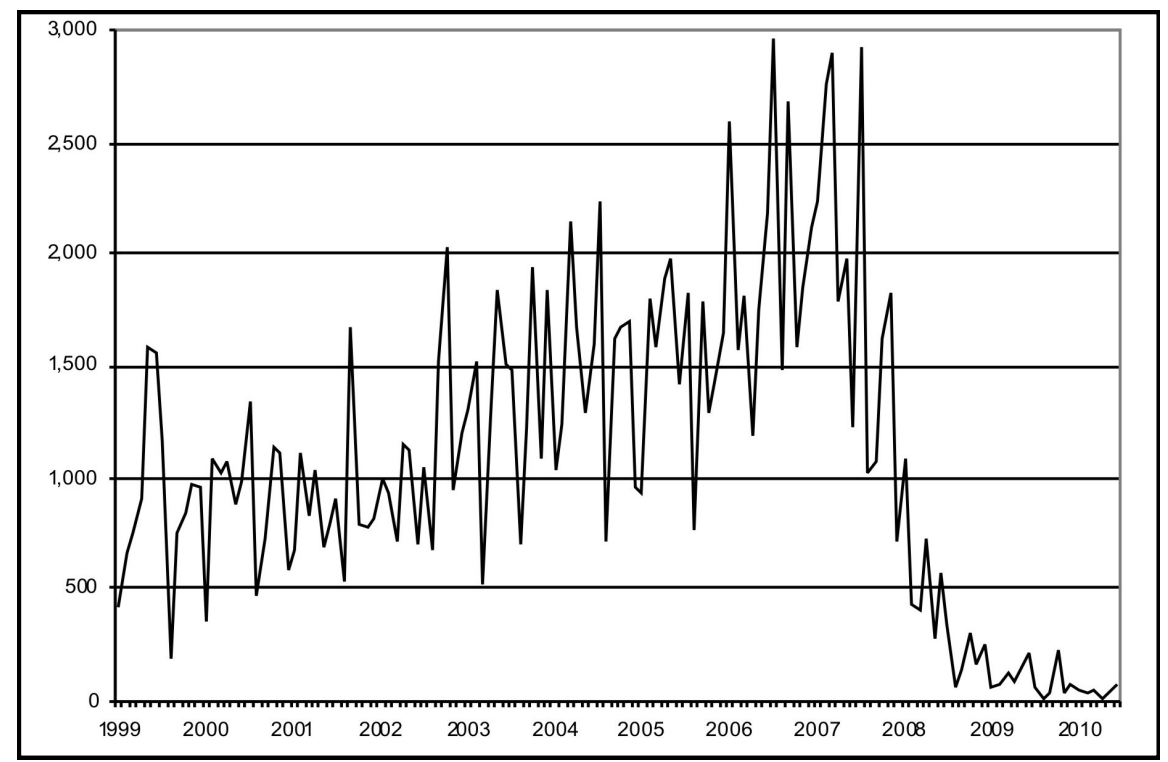

Fig. 3 - Number of new dwellings approved by Colleges of Architects. Province of Castelló. 1999-2010. Source: Castelló Chamber of Commerce. Monthly data.

Various factors contributed to the construction boom: availability of capital, rapid profitability (more in the case of speculators than producers), large areas ripe for development, a favourable political climate and regulations for housing developers, connivance on the part of local governments that obtained substantial income from building permit fees, etc. Other factors worthy of mention were increased incomes, low house prices in Castelló (one of the cheapest areas in Spain), predicted tourist affluence, demographic increase and ready availability of labour, for the most part immigrants. The construction industry became the most important business activity in many places, and there was an atmosphere of confidence that envisaged 
the continual construction of thousands of houses, residential estates, hotels and golf courses. An illuminating example of this confidence is Marina d'Or Golf, in the municipality of Cabanes (population 3,128), which aspired to be the largest leisure and holiday complex in Europe. This project was designed to develop 18 million $\mathrm{m}^{2}$ providing three golf courses, five large hotels, a theme park, artificial ski slopes and almost 40,000 dwellings. The situation changed dramatically, however, after the second quarter of 2007. In June of that year, nearly 3,000 dwellings were approved, but in the first half of 2010 the average per month was just 40 .

In 2007 the economic model based on the ceramic tile and construction sectors suffered a serious downturn, and given the turnover generated during the expansion phase, the crisis spread to all sectors of activity, although in varying levels of intensity. While in agriculture and manufacturing industries employment fell by $25-26 \%$ between the first quarter of 2008 and the second quarter of 2010 , services have weathered the crisis slightly better, with job losses of $11 \%$, in contrast to $50 \%$ of jobs lost in the construction sector. According to the latest Active Population Survey, Castelló has fallen from fourth to tenth place among Spanish provinces in terms of its proportion of industrial sector employees. In contrast, the proportion in the service sectors has increased.

The international crisis has led to the destruction of thousands of jobs in the province of Castelló and millions in Spain. However, most macroeconomic indicators show that in Spain the crisis reached its greatest levels of destruction in the first half of 2009 , since when the rate of decline has slowed up, with more optimistic signs being noted in 2010 (see the Bank of Spain's Economic Bulletin of October 2010).

The labour market and production in the province of Castello are showing similar signs. Between the first and third quarters of 2010, the number of employed increased by 6,800 , although unemployment figures have fallen by only 2,400 , since the active population has increased by 4,300 . Unemployment figures from the Public Employment Service offices also show a reduction of $4.2 \%$ on the peak reached in April of the same year. At the very least, the situation has become stable and jobs are no longer being lost. Monthly figures for employment contracts confirm a similar pattern. The available information for production in 2010 is still incomplete and provisional, but points in a similar direction and results for the key sector in the province, ceramic tile manufacture, seem optimistic.

All the reports and strategic plans published in recent years for the province of Castelló recommend diversifying from a production structure based on existing potentialities and introducing a sustainable development model based on agri-food industries, high-quality ceramic tiles, upmarket construction and specialised tourism. Links between institutions (university-business-administration) should be improved in order to introduce a new model of production based on R\&D\&i, emphasise internationalisation in production and incorporate greater added value in processes and services to businesses and individuals; in short, an economic structure based on the knowledge society and supported by a community with the appropriate human capital.

Because of its particular economic growth, Castelló now has one of largest new citizen populations of all the Spanish provinces, amounting to $18 \%$ of its population, and of the foreign nationalities represented Romanians are at the fore. As in other Spanish regions and cities such as Madrid and Coslada (Şerban and Grigoraş 2000), Castelló emerged as a destination for Romanian migrants in the mid-1990s. Just over ten years ago they had only a token presence (157 residents on 1 January 1998) but since then their numbers have increased 
steadily, especially at the beginning of the new century (Fig. 4), to become the largest foreign community in the province.

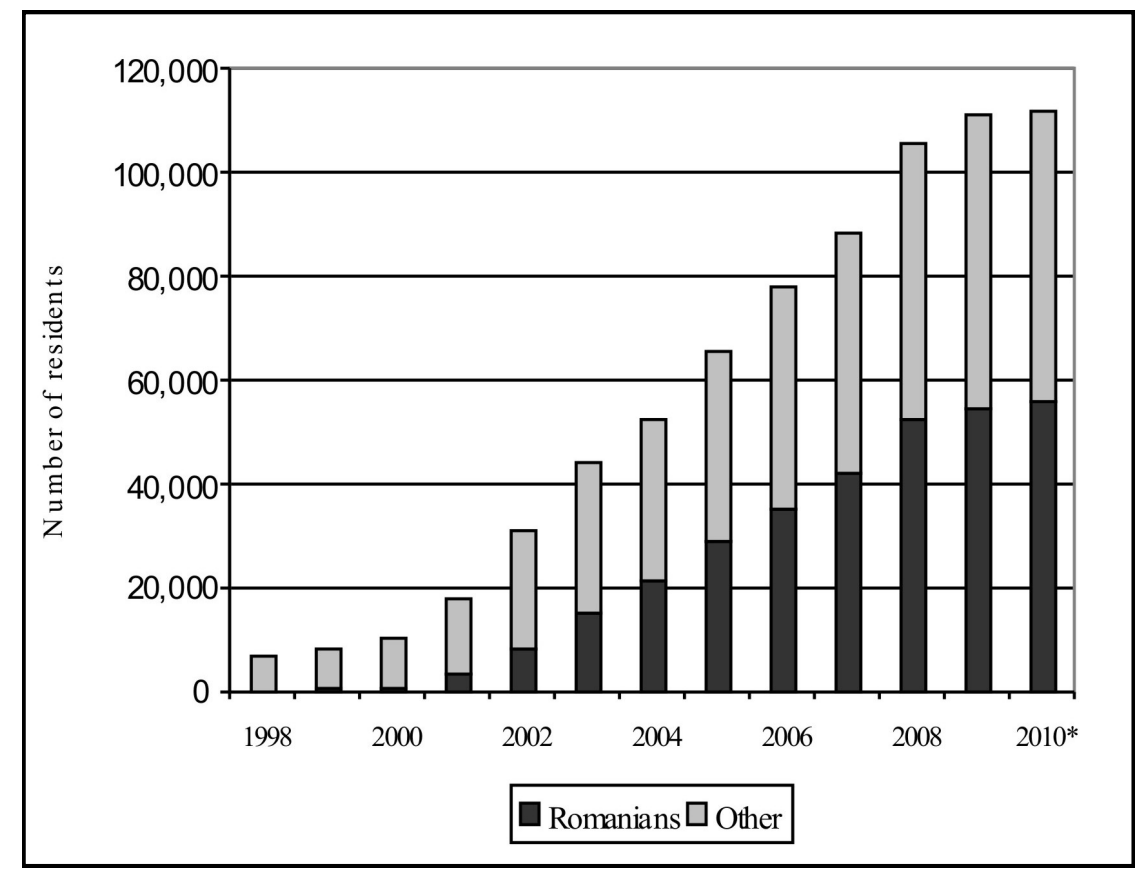

Fig.4 - Evolution of the foreign population resident in the province of Castelló (19982010) * Provisional data. Source: INE, Padrón de Habitantes, www.ine.es

Provisional results of the Padrón de Habitantes for 1 January 2010 report a total of 55,603 registered Romanian citizens, which accounts for half the foreign population $(112,168)$ and almost $10 \%$ of the total population of the province $(603,861)$. The increase in stock has slowed down because of the economic crisis and the slight increase is mainly due to family reunification. Factors that attract immigrants, in addition to those mentioned above for the case of Spain, include the important role of social networks, particularly the Adventist Church in the beginnings of the trend, and higher employment demand.

In absolute figures, the Romanian community in the province of Castello is the second in Spain, far below that of Madrid, and the first in relative terms (Fig. 5). The community are present across the whole province, particularly in the capital and other towns in the ceramic cluster where $82 \%$ of the total Romanian population lives, making it one of the main areas of Romanian settlement in Spain, and undoubtedly, in Europe. The cluster has a high density ( $74 \%$ of the total provincial population live there), a strong economic dynamism and a large, diversified job market $(79 \%$ of all those affiliated to the Social Security system work in the cluster): construction, domestic service, various industries, intensive irrigated agriculture, hotel and catering, and tourism related activities. However, to a large extent the Romanian community has chosen this area because family and friends were already settled there, and can provider security for new arrivals and help them in the social and professional integration process. Social networks help to strengthen already existing concentrations (Arango 2006) and are a key element in the composition and channelling of flows. Immigrants have come to 
Castelló from all regions of Romania, although the first arrivals were predominantly from Târgovişte and Ploieşti in the departments of Dâmbovița and Prahova (Viruela 2002).

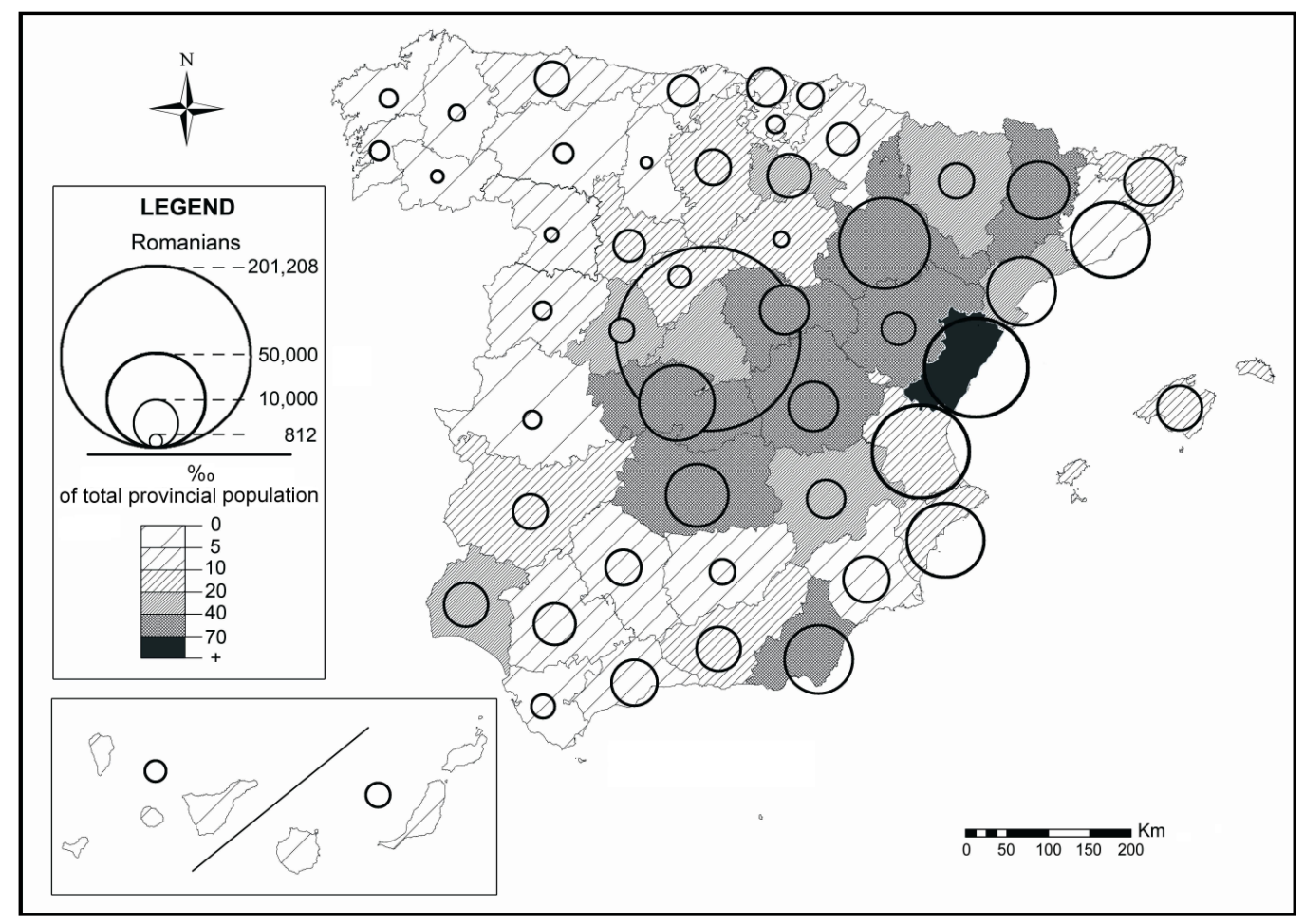

Fig. 5 - Geographical distribution of the Romanian comunities (2009)

The Romanian population in Castelló is characterised by a high proportion of young people of working age, typical of economic migration, and with only slight gender difference. Initially, the proportion of males was higher (56.6\% in 2002 , compared to $52 \%$ today), but in recent years the gap has closed due to family reunification. Around $55 \%$ of the population are between 20 and 39 years old, children under the age of 10 account for $11 \%$ and numbers over the age of 60 are very low. Of note is the growth in the percentage of children compared to a few years ago (Viruela 2002), of whom half of those under five years old were born in Spain (Domingo 2008).

The relatively wider base of the Romanian population pyramid (Fig. 6) reflects family rather than individual migration. Its profile differs from that of other nationalities, such as Moroccan or Colombian immigrants, in which men and women predominate, respectively, and which have different migration strategies. The composition of immigrant communities contrasts with the more ageing Spanish population, of whom $27 \%$ are over 65 years old.

Romanian citizens have had a striking impact on the Castelló labour market and make up the largest group of foreign workers. The figure of 15,198 Romanian workers affiliated to the Social Security system at the end of 2009 (Ministry of Labour and Immigration, 2009 Statistical Yearbook) is three times higher than five years previously (Viruela 2002), and represents $49.7 \%$ of 
all foreigners, with even higher percentages for women. In fact, the presence of women in the labour market is higher than reported in the statistics since many are working in the hidden economy (Pajares 2009).
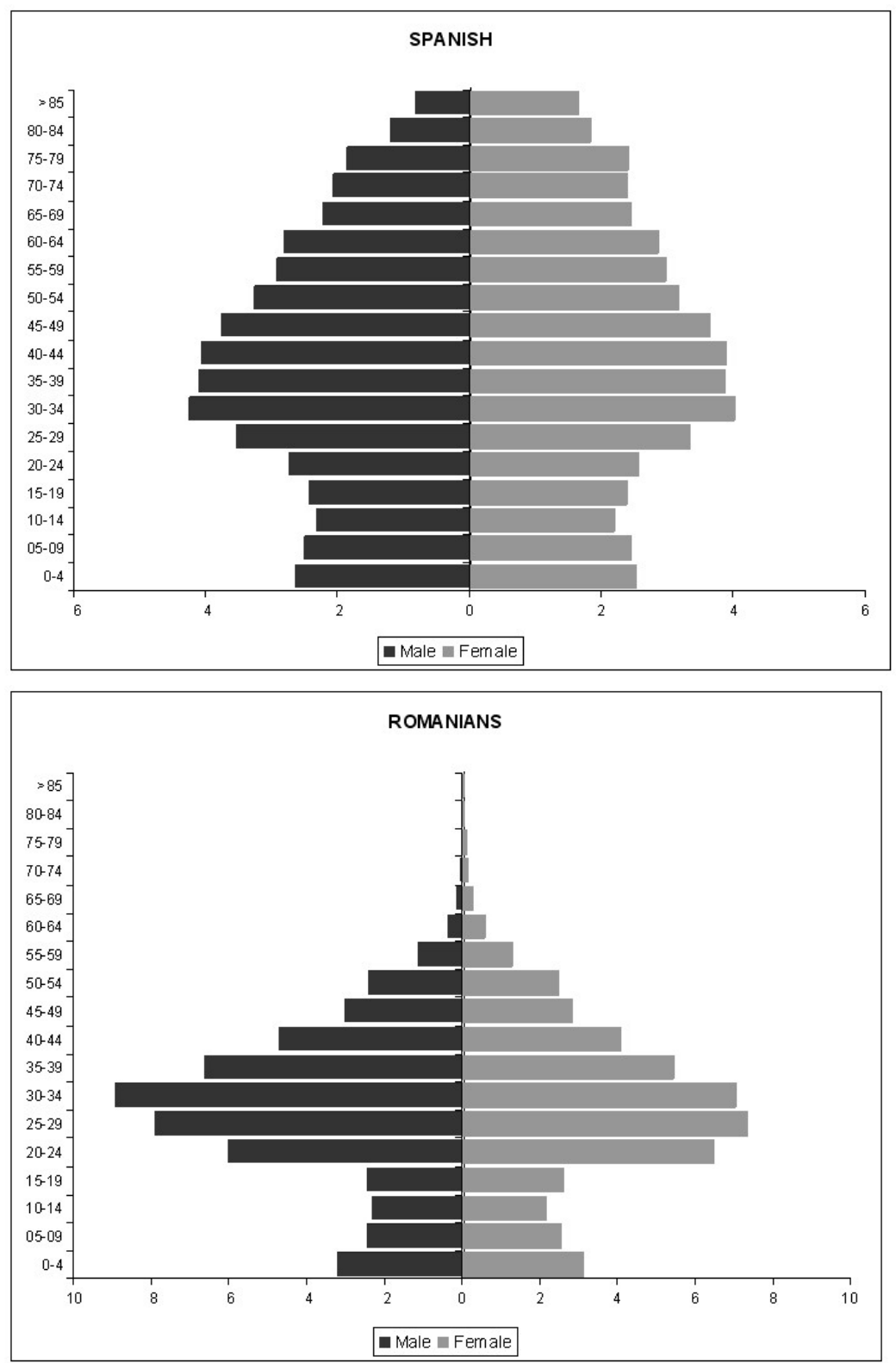

Fig. 6 - Distribution by sex and age of Spanish and Romanian residents in the province of Castelló (1 January 2009) Source: INE, Padrón de Habitantes, www.ine.es 
In Castelló, as in other Spanish provinces (Domingo, Gil and Maisongrande 2008) and countries (IOM 2008), the employment structure of the Romanian population shows clear gender differences (Fig. 7). Most women work in the services sector: $88 \%$ of those interviewed in 2008 (Bernat et al. 2010), especially in the hotel and catering sector and domestic service (which includes caring for the elderly and disabled) and less frequently in commercial or administrative positions, as well as prostitution. On the other hand, $44.6 \%$ of the men interviewed in the same survey worked in the building industry. Salaried workers in low-skilled positions (labourers) predominated, although there were also some skilled workers and a large number of Romanian businesses that frequently sought cheap, mobile labour among their compatriots. In sum, the jobs performed by the Romanian community, namely low and medium skilled positions, are complementary to those of the Spanish population, and have increased in greatest numbers among the foreign population in recent years.

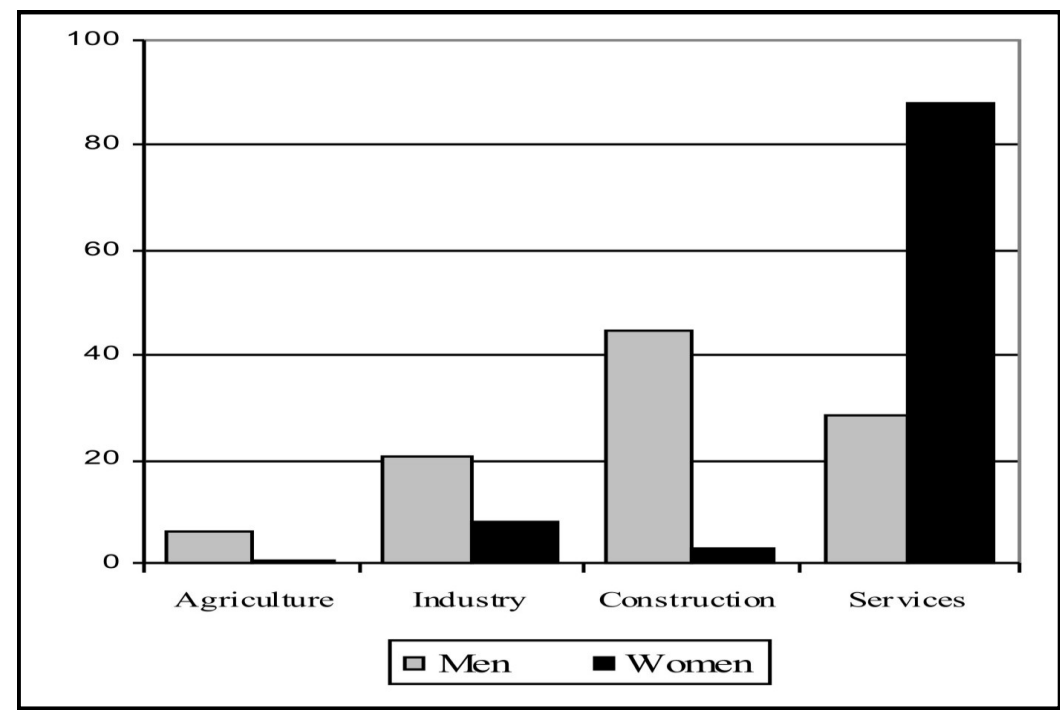

Fig. 7 - Distribution of Romanian workers in Castelló by sector and sex in 2008. Source: Interuniversity Institute for Local Development (IIDL) survey for publication in Bernat et al. 2010.

Romanian immigrants have demonstrated a great capacity to adapt to changing circumstances. Their irregular situation during the initial years (prior to Romania joining the European Union there were more undocumented than authorised Romanians in Spain) did not hinder their rapid incorporation into the labour market, due to the growth of the hidden economy in Castello and their contacts through the social network. Empirical studies show that families and friends provide the main channel for information, intermediation and employment references. Of those surveyed in 2008 , $34 \%$ found work through neighbours and friends, and $25 \%$ through their relatives (Bernat et al., 2010). The established Romanian community network passes on information about vacancies and frequently recommends candidates to prospective employers. Immigrants who arrive without the support of the network are more likely to run into difficulties: most of the jobless surveyed in 2008 had not turned to their families to look for work (Bernat et al. 2010).

Following the entry of Romania into the EU in 2007, a large number of Romanians avoided the 
restrictions imposed by the Spanish government (with certain exceptions, they were not allowed to work as employees) by registering as self employed in the Social Security system. In the whole of Spain, the number of registered self-employed Romanians rose sharply from below 5,000 on 31 December 2006 to over 48,700 in May 2008. Although many were actually 'false self employed', working for others without contracts, these figures reveal the high level of business initiative in the Romanian community. In the province of Castelló, between 300 and 500 Romanian firms have been created in a wide range of sectors (Bucur 2006). Most of these firms consist of the entrepreneur and another family member, although some employ other workers, particularly in the building sector. A further illustration of their adaptability is reflected in Jobs Observatory figures for the last two years, which show an increase in the number of Romanians employed in agriculture in the province of Castelló.

\section{Databases and methods}

We have examined all the statistical information available on the issues dealt with in this study. The National Statistics Institute (INE) was the main data collection organisation referred to, from which we analysed three sources. The first of these was the Padrón de Habitantes, which records the population of the municipality and constitutes proof of residence and usual address. This information is collected by local councils and reviewed and published by the INE. Every person living in Spain is obliged to register with the town or city council. The register is constantly updated, although the information is published on 1 January. The second source was the Residential Variations Statistics, which contains information based on the changes registered in the Padrón de Habitantes, and computes the changes in usual residence over the year. The third source was the Active Population Survey, which is published quarterly and provides data about the workforce and the inactive population. Social Security affiliations were also analysed; these provide detailed information on contracted workers and the self employed. From Inland Revenue data, we analysed the Business Tax database, which is a direct tax on all business, economic or artistic activity except the subsidised primary sector, and as such covers practically the entire self employed population. Finally, we obtained figures on projects approved by the Official College of Surveyors, Technical Architects and Construction Engineers of Castelló; these projects are official documents, without which local councils will not approve planning permission. (See Palacio 2008) for an analysis of the validity of this source.) Quantitative information was supplemented with results taken from the study carried out in June 2008 by the Institute of Local Development at the Universitat Jaume I (for technical details, see Bernat 2010), and in-depth interviews with the heads of key institutions and social agents.

\section{Analysis and results}

The economic crisis, now in its third year, has had negative consequences on the quality of life and future prospects of the foreign population. The recession brought to an end a decade of extraordinary growth in immigration: in 2008 and 2009 the increase in the number of Romanian residents slowed down and may indeed have fallen in 2010, according to indications from National Statistic Institute estimations. In theory, the crisis should trigger a return to the country of origin, but this phenomenon is highly complex and difficult to quantify. In order to assess migration flows, and particularly returns, we now examine the strategies applied to adapt to the new employment context.

The main consequence of the crisis is the destruction of jobs, which has been more keenly felt among the foreign population. Between November 2007 and April 2010 the number of foreigners affiliated to the Social Security system fell by $30 \%$, compared to $20 \%$ among the 
Spanish population. Essentially this is because immigrants are over-represented in sectors that are sensitive to business cycles (construction, hotel and catering, commerce, etc.) and additionally, they occupy unskilled or low-skilled positions with less secure job contracts (Sopemi 2009). Above all, traditionally male jobs have been lost in the construction industry, and the crisis has thus affected men more than women (Table 1). Women are less affected since they are essential to domestic service and other low-skilled jobs that, despite the crisis, are rejected by the Spanish population.

Table 1

Foreign workers affiliated to the Social Security system in Castelló

\begin{tabular}{r|r|r|r|r} 
& \multicolumn{1}{|l|}{ Total } & \multicolumn{1}{l|}{ Men } & Women & \multicolumn{2}{l}{$\begin{array}{l}\text { of } \\
\text { women }\end{array}$} \\
\hline 2001 & 9,607 & 6,992 & 2,615 & 27.3 \\
\hline 2002 & 15,486 & 10,882 & 4,604 & 29.7 \\
\hline 2003 & 16,618 & 11,751 & 4,867 & 29.3 \\
\hline 2004 & 19,597 & 13,552 & 6,045 & 30.8 \\
\hline 2005 & 32,831 & 20,843 & 11,988 & 36.5 \\
\hline 2006 & 36,527 & 23,573 & 12,954 & 35.5 \\
\hline 2007 & 39,561 & 25,763 & 13,798 & 34.9 \\
\hline 2008 & 33,255 & 20,473 & 12,782 & 38.4 \\
\hline 2009 & 30,551 & 18,197 & 12,354 & 40.4
\end{tabular}

Source: Ministry of Labour and Immigration, Statistical Yearbook, http://www.mtin.es/es/estadisticas/contenidos/anuario.htm

Figures show that Romanian women are less likely to lose their jobs than men; between the end of 2007 and the end of 2009, the number of women affiliated to the Social Security system in Castelló increased by four, while the number of men fell by 2,308. If we compare the figure for women in official employment with the total number of immigrants of working age at the beginning and the end of the above-mentioned period, we find a decrease of only two percentage points, from $32 \%$ to $30 \%$. The same statistics for the male population show a drop from $47 \%$ to $35 \%$. Men continue to enjoy a higher rate of employment, but the differences are considerably smaller, and at the end of 2009 Romanian women accounted for $44 \%$ of the total Romanian population in contracted employment.

The unemployment rate, which has always been higher among the foreign workforce, rose suddenly following the collapse of the construction sector. In the second quarter of $2010,19 \%$ of the active Spanish population was unemployed, compared to $44 \%$ of active foreigners, half of whom were Romanian. This high proportion may suggest that many households were suffering severe financial difficulties, and while many are facing economic hardship, it is necessary to examine this question in greater detail. According to the Job Observatory, 16,167 Romanians were in contracted employment on 31 December 2007 in the province of Castelló, and 704 were receiving unemployment benefit. Two years later, these figures were 14,433 and 5,365 , respectively. In other words, although fewer were in contracted employment, the number with a monthly income (whether from a salary or unemployment benefit) increased by almost 3,000 and therefore, household income must have fallen less than suggested by the unemployment statistics. 
The Economic Crisis and Immigration: Romanian Citizens in the Ceramic Tile District of Castello (Spain)

Table 2

Self-employed workers in the city of Castelló

\begin{tabular}{|c|c|c|c|c|}
\hline & December 2007 & March 2010 & $\begin{array}{l}\text { Absolute } \\
\text { variation }\end{array}$ & $\begin{array}{c}\text { Relative } \\
\text { variation }(\%)\end{array}$ \\
\hline TOTAL & 18,498 & 17,552 & -943 & -5.1 \\
\hline Spanish & 17,362 & 16,809 & -553 & -3.1 \\
\hline Foreigners & 1,136 & 743 & -393 & -34.6 \\
\hline Romanians & 726 & 372 & -354 & -48.8 \\
\hline Other foreigners & 410 & 371 & -39 & -9.5 \\
\hline
\end{tabular}

Source: Castelló Chamber of Commerce, Business Tax database. Authors' own statistics

Another category that has felt the impact of the recession is the self employed, a category that grew exponentially following Romania's entry into the EU. The crisis has halved the number of self-employed Romanians in the city of Castelló (Table 2), with the construction sector being the most severely hit (Romania din Spania, 2008). However, it is of note that following the twoyear moratorium on the free movement of workers (which ended on 1 January 2009), some self employed workers switched to contracted worker status, which undoubtedly had an influence on the statistics.

Many workers who have lost their jobs in the building sector, industry, the hotel and catering sector, etc., have looked for work in agriculture. In two years, the number of Romanians contracted in the agricultural sector has increased from below 1,000 in 2007 to over 2,000 in 2009 , in the same period that figures for other nationalities, including Spanish, have fallen. This sector requires workers who are prepared to take seasonal jobs and move from one district to another in exchange for low salaries. Broadly speaking, foreign workers are more willing to move than Spanish workers, and Romanians have an added advantage over other immigrant communities in that they are EU citizens. In the opinion of the provincial secretary of the trade union La Unió, this status "makes contract procedures easier" and moreover "in the end, we have more Romanians than other nationalities; it is a question of supply and an available workforce". In addition, "there is... a reluctance to employ Muslim workers". The same interviewee reported a certain competition in recent months between Spaniards whose unemployment benefit had run out and foreign workers, and stated that "employers are more likely to hire Spaniards than foreigners, especially if they know them".

A further consequence of the crisis is the shift of many immigrants into the hidden economy, where they must endure precarious employment conditions. Romanians are experienced in dealing with this situation, since before Romania joined the EU, numbers of undocumented immigrants exceeded legal residents in Castelló (and in the whole of Spain). In the two following years, although they were allowed residency in Spain, government restrictions meant many had no alternative but the hidden economy. According to both Friedrich Schneider and the Special Management Division of the Inland Revenue, Spain has a large shadow economy that is on the increase in various business sectors. Of all areas of activity, the shadow economy is most vigorous in domestic service, which has a predominance of Romanian women (Viruela 2002). This sector has felt the effects of the recession less harshly since demand has not shrunk; this factor has enabled many families to survive, as illustrated by the following case of a forty-year-old woman whose husband lost his job in the ceramic tile industry and is now claiming unemployment benefit: "I've been working as a domestic help for over a year now because we can't see any other way out. The 400 euros that I earn every month goes a long way to paying the mortgage and keeping our three children" (see "La crisis se ceba en las 
remesas a Rumanía", Las Provincias, 13-IX-2009). Women have taken on a more significant role in the family, while the father figure has been negatively affected by job losses, factors that are affecting the distribution of roles and responsibilities, and may lead to significant transformations in the model of the family.

Those who have been most seriously affected by the crisis turn to friends and relatives for help, and some even receive money from Romania: "their relatives are now sending back what they saved from the remittances of the boom years to help them pay what they owe in Spain" (Ángela Placsintar, Association of Eastern European Immigrants). In general, they seek work more actively and are more likely to turn to associations: "before the crisis we saw an average of two people a day who were looking for information about getting a better job; now I see five who are looking for work" (Romanian Association of Castelló).

The Residential Variation Statistics allow migration flows to be analysed, although with some limitations since not all changes in residence are registered and some are reported several months after the event. Despite these shortcomings, the data show that the crisis has had repercussions on migrations (Table 3). For example, mobility within Spain, which grew rapidly until 2007, has fallen appreciably in recent years, both in terms of flows between other Spanish provinces and in changes of residence within the province of Castello. These findings coincide with those of the Job Observatory, which gathers data on contracts of individuals who move to the province and those of workers who are resident in Castello and are contracted in other provinces.

In addition, the number of arrivals from abroad has fallen dramatically. In 2008 and 2009, arrivals (between 2,200 and 2,400) were approximately $25 \%$ of those registered in previous years (in excess of 9,000). This reversal in the trend was to be expected, since the deteriorating situation of the job market has led potential migrants to wait for recovery before taking the decision to emigrate.

Migration flows of Romanian citizens resident in the province of Castelló

\begin{tabular}{|c|c|c|c|c|c|c|c|c|}
\hline & \multicolumn{3}{|c|}{ Abroad } & \multicolumn{3}{|c|}{ Other Spanish provinces } & \multirow{2}{*}{$\begin{array}{l}\text { Balance } \\
\text { total }(a+b)\end{array}$} & \multirow{2}{*}{$\begin{array}{c}\text { Between } \\
\text { provincial } \\
\text { municipalities }\end{array}$} \\
\hline Year & Immigration & Emigration & $\begin{array}{l}\text { Balance } \\
\text { (a) }\end{array}$ & Immigration & Emigration & $\begin{array}{l}\text { Balance } \\
\text { (b) }\end{array}$ & & \\
\hline 2001 & 1,292 & $\left({ }^{*}\right)$ & & 197 & 106 & 91 & & 220 \\
\hline 2002 & 3,721 & 5 & 3,716 & 287 & 400 & -113 & 3,603 & 813 \\
\hline 2003 & 5,987 & 27 & 5,960 & 394 & 615 & -221 & 5,739 & 1,111 \\
\hline 2004 & 7,251 & 254 & 6,997 & 547 & 917 & -370 & 6,627 & 1,345 \\
\hline 2005 & 6,611 & 199 & 6,412 & 896 & 918 & -22 & 6,390 & 1,736 \\
\hline 2006 & 9,418 & 1,003 & 8,415 & 1,266 & 963 & 303 & 8,718 & 2,209 \\
\hline 2007 & 9,437 & 437 & 9,000 & 1,819 & 1,601 & 218 & 9,218 & 2,259 \\
\hline 2008 & 2,398 & 482 & 1,916 & 1,026 & 1,116 & -90 & 1,826 & 1,327 \\
\hline 2009 & 2,258 & 1,408 & 850 & 816 & 934 & -118 & 732 & 1,250 \\
\hline Total 2001-2009 & 48,373 & 3,815 & 43,266 & 6,432 & 6,636 & -322 & 42,944 & 12,270 \\
\hline
\end{tabular}

Source: INE, Residential Variation Statistics (microdata), www.ine.es

$\left(^{*}\right)$ The INE began publishing information on foreign immigration in 2002 
In contrast, the crisis has led to an increase in migration abroad. In 2009, the number of Romanians resident in Castelló leaving the province was almost a thousand more than in previous years, which in relative terms represents a significant qualitative leap (more than triple). However, those who left in 2009 represented only $2.5 \%$ of the registered population. It is difficult to establish the true figure, however, due to shortcomings in the Spanish statistics system, which fails to capture movements out of the country (Domingo and Recaño 2010) and does not distinguish between return migration and migration to other destinations. Nonetheless, the consulate, immigrant associations and those interviewed all perceive that return and other types of migration have increased during the years of recession. Few Romanians in Castello do not know of at least one relative or friend who has returned to Romania, or has decided to migrate to a different country. "You don't hear so much Romanian spoken in the street now" (Adelina, 33-year old Romanian woman).

Most immigrants see their migration experience as a period in their life that may be longer or shorter according to their objectives and the circumstances. The first studies on Romanian migration reported that the majority planned to return (Şerban and Grigoraş 2000; Potot 2002). The survey undertaken in mid-2008 revealed that $74 \%$ of the Romanian community resident in the province of Castelló intended to return (Bernat et al. 2010), a similar percentage to that obtained $(71 \%)$ in a survey carried out at the same time in the Autonomous Region of Madrid (Sandu 2009). Indeed, return is a factor in all migration processes, a flow that the German geographer Ernest Georg Ravenstein (Grigg 1977; Arango 1985) noted as early as 1885, and that rises in periods of recession.

In times of crisis, the main destination countries adopt measures to encourage return migration, thereby reducing the number of unemployed immigrants, pressure on the labour market and social discontent. Several western European countries (France, Germany, Belgium and Netherlands) introduced repatriation schemes in the mid-1970s and such measures have recently been applied in Spain, the Czech Republic and Japan (McCabe et al. 2009). On 18 June 2008, a European parliament directive urged immigrants to return voluntarily to their countries of origin and in November of the same year the Spanish government approved a voluntary return programme addressed to immigrants from countries outside the European Union. And as in other countries, since 2003 Spain has implemented a programme set up by the International Organisation for Migration to help immigrants in serious difficulties who wish to return to their countries (European Migration Network 2009).

In April 2008, the Romanian government ran a campaign in various Spanish and Italian cities, including Castello, in an attempt to convince Romanians to return home with the promise of employment and business creation grants. The Romanian economy was enjoying an $8 \%$ growth rate and unemployment stood at just 3.5\%, and for a number of years some sectors had been dependent on immigrant workers to make up for labour shortages caused by migration (Carvajosa 2006 and Nistor 2007). The campaign was unsuccessful due to scepticism among the migrant community (Oleaque 2008) and according to the Ministry for Labour and Immigration (see Actualidad Internacional Sociolaboral, no. 121) take-up was very scarce. For this reason, the Romanian government, which had few resources to stimulate return, regarded the Spanish programme as an appropriate measure (Plewa 2009). But because of their European community status, Romanian migrants were unable to take advantage of the scheme. However, given the persistence of the crisis and the rapid increase of unemployment in the Romanian community, in May 2009 the Spanish and Romanian governments signed an agreement to facilitate the return of unemployed Romanian workers or those whose jobs were at risk (European Migrations Network, 2009). We do not have information on the number of Romanians that have returned as a result of this agreement, but we suspect the number is low, 
as in the case of the International Organisation for Migration programme that has been in force in Spain since 2003: as of April 2010 only 414 Romanians across all Spain had taken advantage of this scheme to return home (Pajares 2010).

The latest reports on immigration and the employment market in Spain (Pajares 2009 and 2010) conclude that the figure of returning Romanians is highly significant and that "it is probably the nationality with the largest return rate", although no data are provided to support this hypothesis. From sex and age related changes in the structure of the Romanian community in the province of Castelló, we can infer that returnees are young people and adults in the prime of their working lives, mostly male, probably unemployed and unlikely to find work again easily, or more recent arrivals, although some young couples with small children have also returned.

Romanians endeavour to diversify their strategies in pursuit of financial security and while some members of the family remain in Spain, others go back to explore the possibilities and examine what opportunities are available for either salaried or self-employed work. Others supplement their income in Spain, either from short-term job contracts or unemployment benefit, with income from seasonal work in Romania. An increasing number of people from the Romanian community in Castelló travel relatively frequently between their place of origin and Castelló, or move to other countries, thus falling into the category of transmigrants. The SERVEF (Valencian employment and training service) offices, through EURES (European job mobility service), have attended Romanian citizens requesting information about employment vacancies in other European countries (Martínez 2010), which illustrates how the Romanian community live between two or more countries, their place of origin and their migration destination or destinations. By dividing their time between Spain and Romania now restrictions to free movement have disappeared, Romanians can enjoy greater mobility, a factor that can help make their migration experiences more successful. Low cost airlines and coach lines enable them to travel at relatively reduced prices. Circular migration allows them to be more financially adaptable, and strengthens family and social links in both countries; it avoids the disadvantages associated with traditional linear migration and increases social capital. In addition, business opportunities or chances of promotion are increased through the development of economic, social and cultural links between the two countries.

Although migration of Romanians from Castelló, whether to Romania or elsewhere, is higher than in previous years, it is not a massive flow. Three years into the recession, the majority have decided to stay, at least for the moment. The factors that dissuade return include the high cost of arriving and settling in Spain and the high level of integration that many immigrants have attained, with corresponding social and professional improvements. Family migration, an important factor in this community, makes return less likely. Their children have established friendships and emotional bonds and are integrated into the Spanish education system and "keep their parents in Castelló" (María, 38 years old). Many families have bought their own flat or house thanks to the earnings of various members of the family, which might have amounted to "3,000 or 4,000 euros or more. Now some people have lost their jobs and they have to keep paying the mortgage on a flat they can't sell - before they move away - because of the sluggish housing market" (José Antonio, president of Horfi Ingenieros Consultores). Others view the recession as temporary and regard the situation in Romania as even worse; they are reticent to go back "because Romania is one of the countries that is suffering most in this crisis... it's impossible to find work there" (Pancsintar, president of the Association of Eastern European Immigrants). The majority benefit from the Spanish welfare system, and therefore factors such as unemployment benefit, a free quality health system, education grants, the possibility of working while claiming unemployment benefit all hinder the decision to go back. 
Young university graduates will exhaust all possibilities before considering the idea of migrating: "I have just applied for a grant to do my doctoral thesis, which at least would be enough to keep me for three years" (Adelina).

Moreover, the decision to return depends essentially on the situation in the country of origin. The crisis in the destination country might give rise to expectations to return among the migrant population, but these expectations will only materialise if the situation at home is better than it was when they left, as illustrated by the case of Poland (Fix et al. 2009). Since 2008 Romania has also been seriously affected by the international recession, and demand in the Romanian labour market is not sufficient to absorb all returnees.

\section{Discussion}

Extraordinary economic expansion resulted from the model of production developed in Castello in the 1990s, based on intense use of unskilled labour and sectors dependent on international market forces. The shortage of local human capital to meet labour market demands generated a powerful call effect that soon attracted Romanian immigrants. This community settled with relative ease due to migration networks, and as the area was not a traditional migrant destination, very little competition was encountered from other communities of new citizens, which led to an exponential rise in the number of Romanian workers between 2001 and 2007. The business community demanded workers from outside the area, local administrations turned a blind eye to the restrictive border regulations in force and recent arrivals took advantage of opportunities to integrate into the host society without any significant xenophobic reaction. To a large extent, this acceptance was due to the host society's subconscious collective memories of when it had been a poor migrant community. The province thus became home to one of the largest economic immigrant populations in Spain.

The international financial crisis has had dramatic consequences for the province, and the traditional model of production has been thrown into confusion. Unemployment has soared, the construction industry has plummeted and the industrial sector has shrunk significantly. The crisis has most affected the weakest sectors (young people, the unskilled and new citizens), but the Romanian community in Castelló, particularly the women, has demonstrated an enormous resilience to adversity. The Romanians have great advantages over other immigrant communities, especially in their ethnicity and cultural similarity, local recognition of their high level of training and professional skills and their EU member status.

The recession has brought many difficulties for the vast majority of these new citizens, but they have not decided to return home. The return programmes agreed between Spain and Romania have had very little take-up, repeating a pattern almost always seen in other countries and periods (Sopemi 2008 and 2009). It is a mistake to consider the migrant population as a necessary labour force in times of economic expansion that can be dispensed with when crisis hits. Migrants are economic agents, but above all they are people, social beings that put down roots and build relationships in the host community. Moreover, schemes designed to incentivise return generally fail because it is the immigrant who takes the final decision, and this does not depend only on the economic and employment situation in the destination country, but more importantly, in the country of origin. In Romania, the effects of the recession were not noted as immediately as in Spain and other western countries, but the situation has deteriorated rapidly since the beginning of 2009: job losses, fewer job vacancies and increased unemployment; circumstances that do not entice Romanians to return. Some migrants, though not all, will return when the job market stabilises and they can be sure of higher salaries and better professional opportunities. But these objectives seem far from attainable, particularly in the 
short term; foreign investment has fallen and the European Union funds needed to boost the economy and modernise the country are in short supply. In the end, what is decisive is the migrant's vision of the future of his or her nation, and at present there are no motives for optimism. A large majority think, "I'll stay here rather than go back to earn a pittance in Romania".

The immigrant population, and in particular the Romanians in the province of Castelló, now form part of the current system of production and they will continue to do so in the coming years. Spain cannot manage without them for numerous reasons (demographic, employment, fiscal, cultural, etc.,), all of which suggest that the present immigrant stock will on the whole remain stable, and once the recession is over migration flows will recover, albeit with different characteristics. But like the rest of the population, they will also have to adapt to new labour market needs.

Since the beginning of 2010 many indicators show optimistic signs of recovery, but everything indicates that the model of production in Castelló, as in the rest of Spain, will have to undergo a thorough restructuring and that the new labour market requirements will be different from those of the past decade. The type of worker will be highly trained, qualified and skilled, willing to be flexible over working hours and geographical mobility, with business initiative and able to be self employed, open to retraining and life-long learning, sensitive to gender issues, and with high relational capital. In addition, Romanian migrants must overcome their distrust of people and institutions and continue to demonstrate the huge capacity for integration into the labour market that they have become known for.

\section{Conclusions}

The links between the economies of Romania and Castello will continue to be strengthened in the coming years. The host society will become more deeply multicultural and the CastellóRomania medley will be one of its essential components. Now more than ever, and not only for reasons of solidarity but because of socio-economic interests, Spain needs to improve its policies of integration. In order to avoid social tensions, all levels of government must guarantee the principle of equal opportunities and manage diversity in the right way. Both the society of Castelló and the Romanian community must take advantage of the potentials this diversity offers to ensure that the present welfare system remains sustainable.

\section{References}

ARANGO, J. (1985), The 'migration laws' of E. G. Ravenstein, one hundred years on, Revista Española de Investigaciones Sociológicas, no. 32: 7-26, (in Spanish).

ARANGO, J. (2006), Immigration in Spain: an overview, in J. Aragón, Documentos del Seminario sobre Inmigración, Políticas Migratorias y Sindicalismo, Madrid, Fundación $1^{\circ}$ de Mayo: 23-40, (in Spanish).

BECATTINI, G. (1987), The Market and local forces: the industrial district, Bologna, II Mulino, (in Italian).

BERNAT, J. S. et al. (2010), A study of social capital based on social networks and its contribution to socio-economic development: the Romanian immigrant community in the province of Castelló, Cuadernos de Investigación, no. 13, Ceimigra, València, Tirant lo Blanc, (in Spanish).

BUCUR, R. (2006), Romanian immigrants' entrepreneurial initiatives in local economic development in the province of Castelló (Spain), Castelló, Universitat Jaume I, I Jornadas de trabajo MEDIMIGRA, 30 November-1 December, mimeo, (in Spanish). 
CARRERAS, A., TAFUNELL, X. (Coord.) (2005), Spanish historical statistics: nineteenth and twentieth centuries, Bilbao, Fundación BBVV, $2^{\mathrm{a}}$ ed., 2 vols., (in Spanish).

CACHÓN, L. (2009), Migrant Spain: discriminatory framework, labour market and integration policies, Barcelona, Anthropos, (in Spanish).

CARBAJOSA, A. (2006), Romania imports Chinese workers, El País newspaper, 11 November 2006, (in Spanish).

DOMINGO, A., GIL, F., MAISONGRANDE, V. (2008), The labour integration of Romanian and Bulgarian immigrants in Spain, Cuadernos de Geografía, no. 84: 213-236, (in Spanish).

DOMINGO, A., RECAÑO, J. (2010), The reversal of the international migration cycle in Spain: impact and demographic consequences, in Aja, E., Arango, J. and Oliver, J. (eds.), Anuario de la Inmigración en España: la inmigración en tiempos de crisis, Barcelona, CIDOB: 182-207, (in Spanish).

DOMINGO, C., VIRUELA, R. (2001), Channels and networks in the Spanish migration process, Scripta Nova, Revista Electrónica de Geografía y Ciencias Sociales, no. 94 (8), http://www.ub.es/geocrit/sn-94-8.htm, (in Spanish).

DOMINGO, C. (2008), Demographic characteristics of Bulgarian and Romanian immigrants in Spain, Cuadernos de Geografía, no. 84: 195-212, (in Spanish).

FIX, M. et al. (2009), Migration and the Global Recession, Washington, Migration Policy Institute, http://www.migrationpolicy.org/pubs/MPI-BBCreport-Sept09.pdf.

FUERTES, EUGENIO, A. M. (Dir) (2005), The ceramic tile industrial district. Keys to competitiveness in the economy of Castelló, Castelló, Fundación Dávalos-Fletcher, (in Spanish). Spanish)

GARCÍA, FERNÁNDEZ, J. (1965), Spanish overseas immigration, Barcelona, Ariel, (in

GARMENDIA, J. A. (1981), Spanish migration at the crossroads. A general framework of return migration, Madrid, Centro de Investigaciones Sociológicas, (in Spanish).

GIMENO, C. and BERNAT, J. S. (2006), Equal but less so: the Romanian community in Castello, in Bernat ,J. S. and Gimeno, C. (eds.), Migración e interculturalidad. De lo global a lo local, Castelló, Universitat Jaume I: 169-217 (in Spanish).

GIMENO, M. J. (Dir. and Coord.) (1999), The province of Castellón, Castelló, Diputación Provincial de Castelló, (in Spanish).

GRIGG, D. (1977), E. G. Ravenstein and the 'laws of migration'", Journal of Historical Geography, vol. 3, no. 1: 41-54.

INE, Population and Housing Census 2001, Residential Variation Statistics, Continuous Municipal Register (Padrón de Habitantes), www.ine.es, (in Spanish).

IOÉ, Colectivo (2004), Just as human. Stories of the integration of migrants with problems in the Valencian Autonomous Region, Valencia, CEIM et Conselleria de Benestar Social., (in Spanish).

IOM (2008), Migration in Romania: A Country Profile 2008, Geneva, International Organization for Migration, www.iom.int.

MARSHALL, A. (1891), Industry and Trade, London, MacMillan.

MARTíNEZ, N. (2010), Only one thousand Castelló residents see working in Europe as an employment solution, El Periódico Mediterráneo (newspaper), 11-III-2010, http:// www.elperiodicomediterraneo.com/noticias/noticia.asp?pkid=541813,(in Spanish).

MARTÍNEZ, N., SHAW, C. (1994), Spanish emigration to America, 1492-1824, Colombres, Fundación Archivo de Indianos, (in Spanish).

McCABE, K. et al. (2009), Pay to Go: Countries Offer Cash to Immigrants Willing to

Pack Their Bags, Migration Policy Institute, http://www.migrationinformation.org/Feature/ display.cfm?ID=749

MEMBRADO, J.C. (2001), The ceramic industry on the Castellón plain, Diputación 
Provincial de Castelló, Castelló, (in Spanish).

MINISTRY OF LABOUR AND IMMIGRATION, Statistical Yearbook, Various years, http://www.mtin.es/es/estadisticas/contenidos/anuario.htm, (in Spanish).

MINISTRY OF LABOUR AND IMMIGRATION, Immigration Statistical Yearbook, Various years, http://extranjeros.mtin.es/es/InformacionEstadistica/Anuarios/, (in Spanish). NARANJO, C. (1992), Spanish emigration to Latin America: a quantitative analysis, in History of Spanish emigration to Latin America, t. 1: 177-200, (in Spanish).

NISTOR, S. (2007), Romania: the Romanians leave, the Chinese arrive, Le Courrier des Balkans, 18 April 2007, (in French).

JOB OBSERVATORY, The labour market. Castellón, Madrid, Servicio Público de Empleo Estatal, Ministerio de Trabajo e Inmigración, Several years, (in Spanish).

OLEAQUE, J. (2008), The Romanians are still not returning, El País newspaper 14 April 2008, (in Spanish).

PAJARES, M. (2009), Immigration and the labour market. 2009 Report, Madrid, Observatorio Permanente de la Inmigración, Ministerio de Trabajo e Inmigración, (in Spanish). PAJARES, M. (2010), Immigration and the labour market. 2010 Report, Madrid, Observatorio Permanente de la Inmigración, Ministerio de Trabajo e Inmigración, (in Spanish). PALACIOS, A. J. (2008), Statistical sources on Spanish housing: an obstacle to housing policy design, Scripta Nova, Vol. XII, no. 270, http://www.ub.es/geocrit/sn/sn-270/sn-27038.htm, (in Spanish).

PLA JULIÁN, I. (Coord.) (2008), The pros and cons of turning to domestic employment, Col·lecció Quaderns Feministes, 8, Valencia, Institut Universitari d’Estudis de la Dona, (in Spanish).

PLEWA, P. (2009), Spain's Voluntary Return Program: Early Mechanisms and Early Responses, Update 1i: The 2008/2009 Financial Crisis, http://www.age-of-migration.com/na/ financialcrisis/updates/1i.pdf

POTOT, S. (2002), Transnational migrants: a new social category in Romania , Revue d'Études Comparatives Est-Ouest, vol. 33, no. 1: 149-177, http://lames.mmsh.univ-aix.fr/ potot\%20migrants\%20transnat\%202002.pdf, (in French).

RED EUROPEA DE MIGRACIONES. ESPAÑA, (2009), Programmes and strategies on the assisted return and integration of third-county migrants, Madrid, Observatorio Permanente de la Inmigración, Ministerio de Trabajo e Inmigración, http://extranjeros.mtin.es/es/ RedEuropeaMigraciones/Estudios monograficos/EMN-ES-2009-I-Retorno Asistido-ES.pdf, (in Spanish).

REHER, D. and REQUENA, M. (Eds.) (2009), The multiple faces of immigration in Spain, Madrid, Alianza editorial, (in Spanish).

ROMANIA DIN SPANIA, 200 Romanian construction firms close in Castellon in one year, http://www.romaniadinspania.com/ (8 July 2008), (in Spanish).

SALOM, J., ALBERTOS, J. M. (2006), Institutional networks and services to the firms in the Castellón ceramic tile cluster, Scripta Nova, vol. X, no. 213, http://www.ub.es/geocrit/sn/sn213.htm, (in Spanish).

SÁNCHEZ ALONSO, B. (1995), The causes of Spanish migration 1880-1930, Madrid, Alianza, (in Spanish).

SÁNCHEZ ALBORNOZ, N. (1988), Spanish movement to America: mass migration, 1880-1930, Madrid, Alianza, (in Spanish).

SANDU, D. (2007), Emergent transnational migration in Romanian villages, Migraciones, no. 21: 77-112, (in Spanish).

SANDU, D. (Dir.) (2009), Romanian communities in Spain, Fundația Soros România http://www.osf.ro/ro/comunicate detaliu.php?comunicat=85\#, (in Romanian).

ŞERBAN, M., GRIGORAŞ, V. (2000), The 'dogeni' from Teleorman at home and abroad. A study on circular migration to Spain”, Sociologie Românească, no. 2: 92-120. 
The Economic Crisis and Immigration: Romanian Citizens in the Ceramic Tile District of Castello (Spain)

SOPEMI, International Migration Outlook, Rapport annuel 2008 et Rapport annuel 2009, Paris, Organisation de Coopération et de Développement Économiques, (in French).

VILAR, J. B. (2004), The Spanish in North Africa: a forgotten migration cycle, 1830-1962, in VACA, A. (ed.), Minorities and migrations in history Salamanca, Publicaciones de la Universidad de Salamanca: 205-233, (in Spanish).

VIRUELA, R. (2002), The new immigration current of Eastern Europe, Cuadernos de Geografía, no. 72: 231-258, (in Spanish).

VIRUELA, R. (2004), The resource of emigration. Balance during the transition in Romania, Papeles del Este, no. 9, http://revistas.ucm.es/cee/15766500/articulos/ PAPE0404220011A.PDF, (in Spanish).

YÁÑEZ, C. (1994), Spanish migration to America $\left(19^{\text {th }}\right.$ and $20^{\text {th }}$ centuries). Quantitative dimension and characteristics, Gijón, Fundación Archivo de Indianos, (in Spanish).

Initial submission, November 5, 2010

Revised submission, December 29, 2010

Final acceptance, April 28, 2011

Correspondence: Jaume I University, 12071 Castelló de la Plana, Castelló, Spain.

E-mail: bernat@eco.uji.es, rafael.viruela-martinez@uv.es 